\title{
TANGGUNG JAWAB DALAM KEPEMIMPINAN
}

\author{
Masniati \\ Universitas Muhammadiyah Palembang \\ ita.ilet44@gmail.com
}

\begin{abstract}
Humans as the only creatures in creation Allah Almighty the conditions with perfection compared to Allah's creation others, namely angels, jinn, animals and plants.Human perfection because of the mandate given by Allah swt to become a figure of God's representative creature on earth, namely as the caliph of Allah swt., as a leader who is in charge and responsible cultivate, organize, maintain and prosper earth.

Duties and responsibilities given by Allah The SWT is very big and heavy, so it's not one also other creatures of Allah who are able to receive it (Surah Al-Ahzab [33]: 72.). Tasks and leadership responsibilities as servants, caliphs or as a leader on earth is a divine mandate need al-mas'uliyyah (responsibility) for God's grace given to humans, good in the form of position (servant as well as caliph) or so many favors. Humans are obliged to submit an "accountability report" at before Allah upon the abundance of Divine gifts given to him.

Al-Qur'an and Hadith of the Prophet Muhammad are very valid text to be able to know the essence leadership properly and completely, which can guide and be guided by humans in implementing leadership duties and responsibilities. With so, this paper will present about leadership in an Islamic perspective.

Keywords: Leadership and responsibility
\end{abstract}




\begin{abstract}
Abstrak
Manusia sebagai satu-satunya makhluk ciptaan Allah swt yang lengkap dengan kesempurnaan dibandingkan dengan makhluk ciptaan Allah swt yang lain, yakni malaikat, jin, hewan dan tumbuh-tumbuhan. Kesempurnaan manusia karena amanah yang diberikan oleh Allah swt untuk menjadi sosok makhluk wakil Allah di bumi, yakni sebagai khalifah Allah swt., sebagai pemimpin yang bertugas dan bertanggung jawab mengolah, mengatur, memelihara dan memakmurkan bumi.

Tugas dan tanggung jawab yang diberikan Allah swt tersebut sangat besar dan berat, sehingga tak satu pun makhluk Allah swt yang lain yang sanggup untuk menerimanya (QS. Al-Ahzab [33]: 72.). Tugas dan tanggung jawab kepemimpinan sebagai hamba, khalifah atau sebagai pemimpin di bumi adalah amanah ilahi yang membutuhkan al-mas'uliyyah (tanggung jawab) atas anugerah Tuhan yang diberikan kepada manusia, baik berupa jabatan (hamba sekaligus khalifah) maupun nikmat yang sedemikian banyak. Manusia berkewajiban untuk menyampaikan "laporan pertanggungjawaban" di hadapan Allah atas limpahan karunia Ilahi yang diberikan kepadanya.
\end{abstract}

Al-Qur'an dan Hadis Rasulullah saw merupakan teks yang sangat valid untuk dapat mengetahui hakikat kepemimpinan secara baik dan utuh, yang dapat menuntun dan dipedomani manusia dalam melaksanakan tugas dan tanggung jawab kepemimpinan. Dengan demikian, tulisan ini akan menyajikan tentang kepemimpinan dalam persfektif islam.

Kata Kunci: Kepemimpinan dan tanggung jawab 


\section{PENDAHULUAN}

Secara universal, manusia adalah makhluk Allah yang memiliki potensi kemakhlukan yang paling bagus, mulia, pandai, dan cerdas, mendapatkan kepercayaan untuk menjalankan dan mengembankan amanah serta memperoleh kasih sayang Allah swt yang sempurna.

Sebagai wujud kesempurnaan, manusia diciptakan oleh Allah swt memiliki dua tugas dan tanggung jawab besar. Pertama, sebagai seorang hamba ('abdullah)2 yang berkewajiban untuk beribadah sebagai bentuk tanggung jawab 'ubudiyyah terhadap Tuhan sebagai pencipta.3 Kedua, sebagai khalifatullah yang memiliki jabatan ilahiyah sebagai pengganti Allah swt dalam mengurus seluruh alam.4 Dengan kata lain, manusia sebagai khalifah berkewajiban untuk menciptakan kedamaian, melakukan perbaikan, dan tidak membuat kerusakan, baik untuk dirinya maupun untuk makhluk yang lain.

Dengan Tugas dan tanggung jawab tersebut, menunjukan bahwa manusia merupakan pemimpin, melaksanakan tugas kepemimpinan di bumi sebagai amanah dari sang pencipta. Dalam kehidupan sosial, suatu masyarakat tidak dapat dipisahkan dari sebuah kepemimpinan.6 Kepemimpinan dibutuhkan setiap hari, baik dalam lingkungan keluarga atau rumah tangga, dalam pekerjaan di kantor atau di perusahaan, dan dalam aktifitas-aktifitas kehidupan sosial lainnya dalam masyarakat.

Kepemimpinan merupakan suatu ilmu, suatu seni, dan suatu profesi seseorang. Sebagai ilmu, kepemimpinan itu dapat dipelajari oleh siapa pun juga, hanya penerapannya perlu disesuaikan dengan situasi dan kondisi yang dihadapi. Sebagai bakat dan seni, kepemimpinan berarti menguasai seni dan teknik melakukan tindakan-tindakan, seperti teknik memberikan perintah, memberikan teguran, memberikan anjuran, memberikan pengertian, memperoleh saran, memperkuat identitas kelompok yang dipimpin, memudahkan pendatang baru untuk menyesuaikan diri, menanamkan rasa disiplin di kalangan bawahan, serta membasmi desas-desus, dan lain sebagainya. kepemimpinan, sebagai profesi, bukan merupakan pembawaan dan keturunan, tetapi suatu kemauan, kemampuan, kesanggupan, dan kecakapan seseorang untuk memahami asas kepemimpinan yang 
sehat, menggunakan prinsip-prinsip, sistem, metoda, dan teknik kepemimpinan yang sebaik- baiknya, memahami konsepsi dasar kepemimpinan, serta berfikir dengan seksama, mempunyai pengetahuan, pengalaman, dan mampu menyusun rencana tentang apa yang akan dilaksanakan dan tujuan yang akan dicapai. berkaitan dengan kepemimimpinan, Rasulullah saw merupakan sosok pemimpin yang mencontohkan kepemimpinan secara sempurna. Allah swt dalam al-Qur'an memproklamirkan Rasulullah saw sebagai teladan yang sempurna dalam melakoni kepemimpinan.

Oleh karena itu, Hadis Rasulullah saw merupakan teks yang sangat valid untuk dapat mengetahui model, metode, tehnik bahkan seni kepemimpinan secara baik dan utuh.

\section{Klasifikasi dan Kategorisasi}

Berdasarkan hasil penelusuran pada kegiatan takhrīj al-ḥadīis, ditemukan banyak hadis yang berkaitan dengan kepemimpinan, sebagaimana uraian metode pencarian hadis. Namun yang dapat dikemukakan sebagai upaya kategorisasi atau klasifikasi hadis tersebut berdasarkan al-takhrij al- hadis sesuai tema pembahasan yakni hadis mengenai kepemimpinan dalam tinjauan ontologis, yakni hadis tentang hakikat kepemimpinan, terdiri atas 8 riwayat dalam Sahih al-Bukhari, 1 riwayat dalam Sahih Muslim, 1 riwayat dalam Sunan al-Turmuzi, 1 riwayat dalam Sunan Abu Dawud dan 4 dalam Musnad Ahmad yang dideskripsikan pada lampiran makalah ini. Berikut dideskripsikan masig-masing 1 riwayat saja, sebagai berikut:

\section{Hadis Riwayat Bukhari}

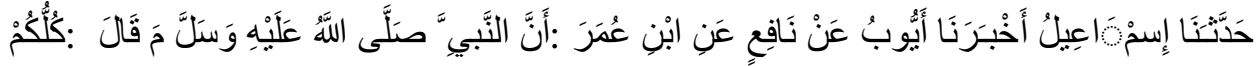

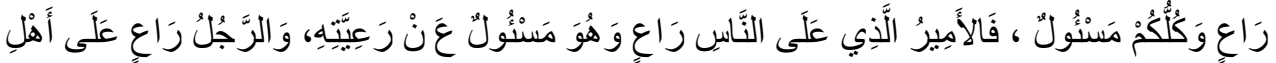

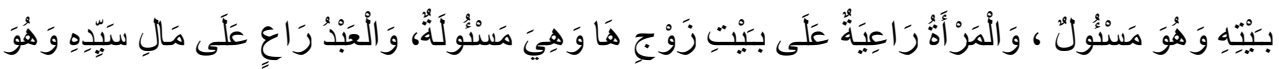

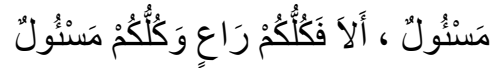




\section{Hadis Riwayat Muslim}

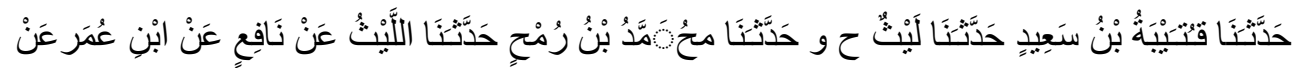

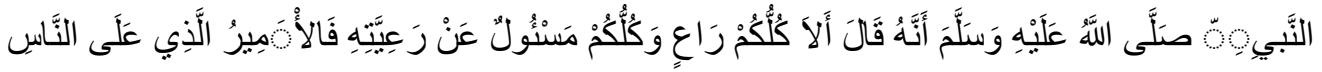

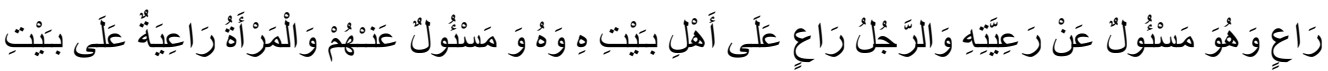

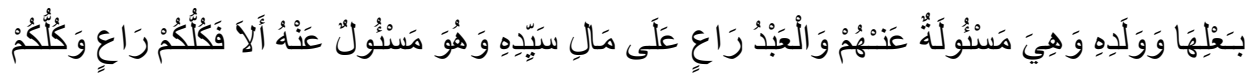

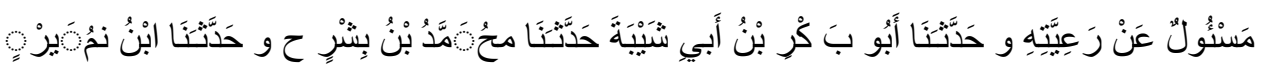

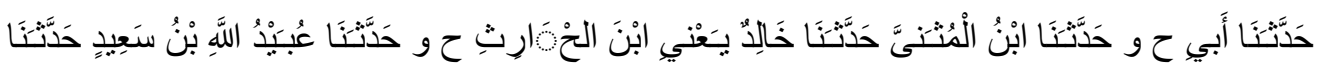

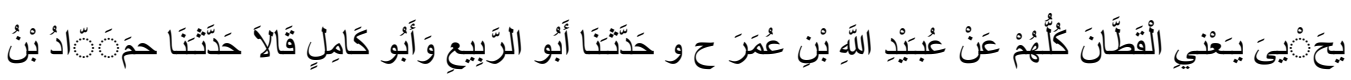

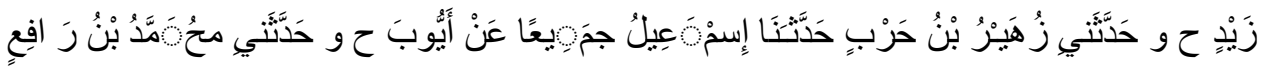

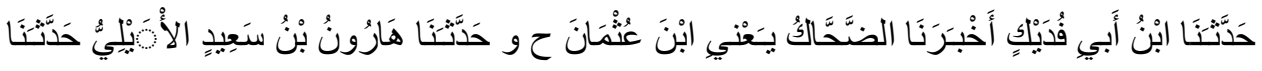

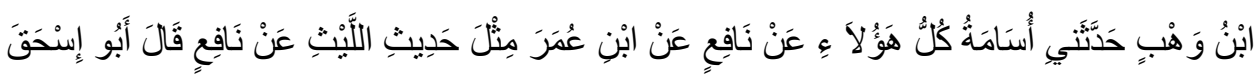

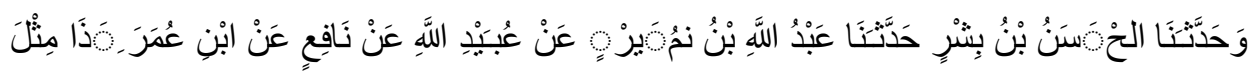

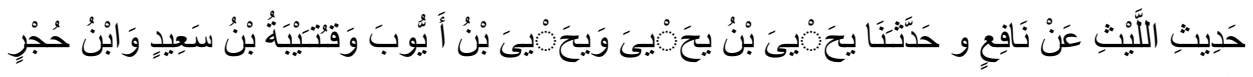

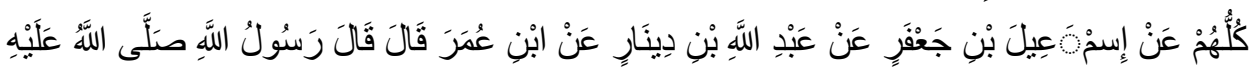

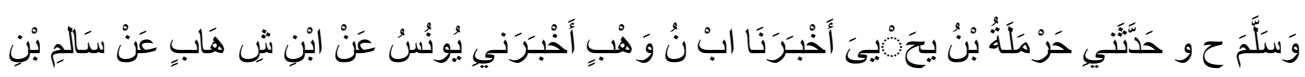

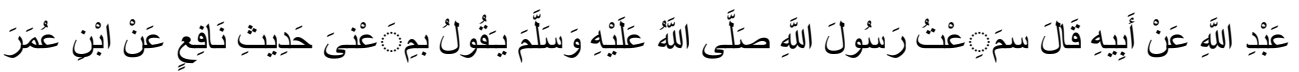

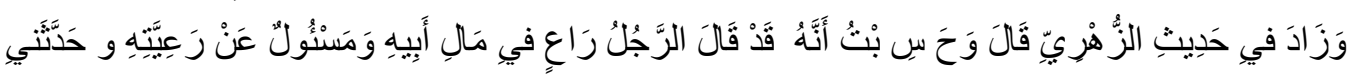

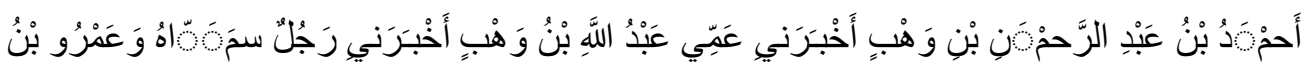

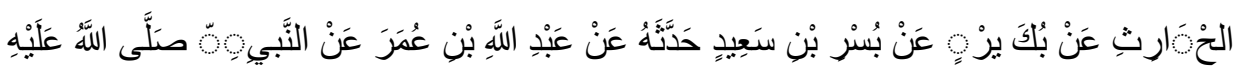

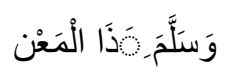

Hadis Riwayat Abu Daud

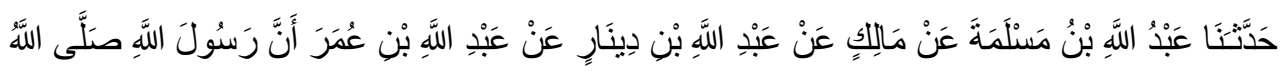

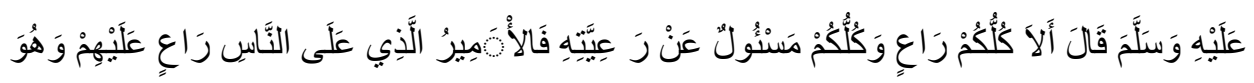

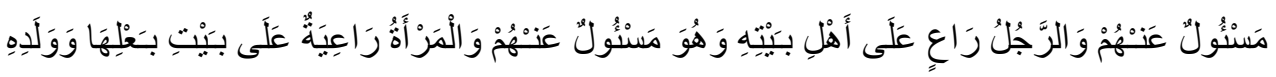

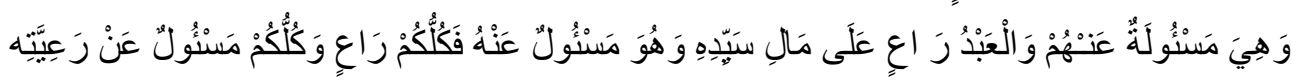




\section{Hadis Riwayat Tirmidzi}

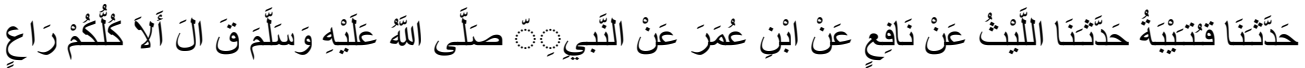

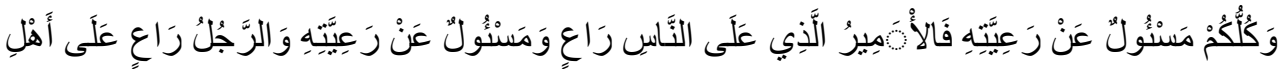

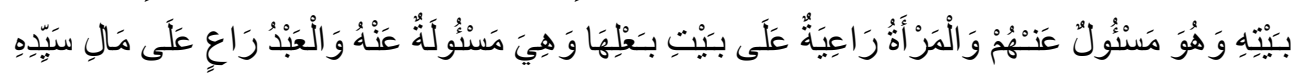

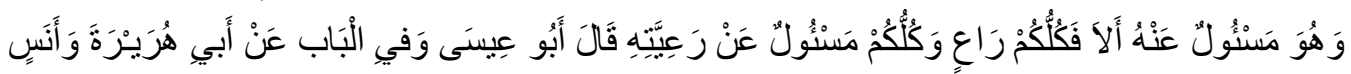

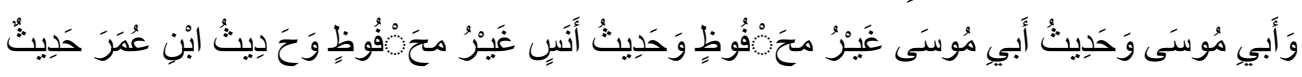

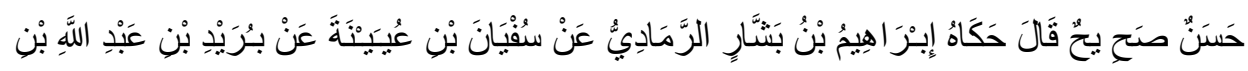

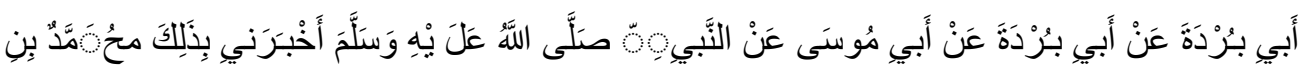

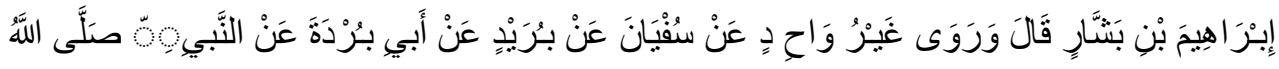

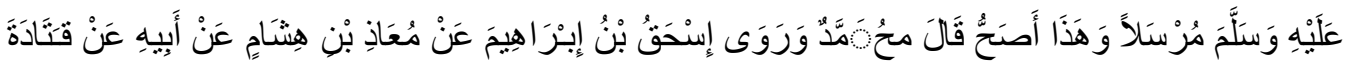

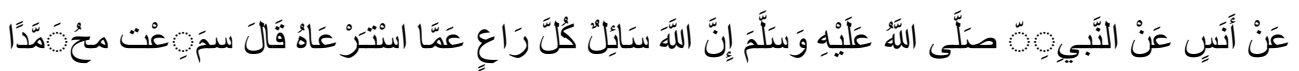

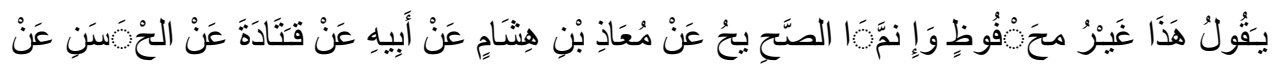

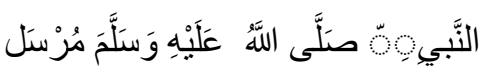

Hadis Riwayat Ahmad bin Hanbal

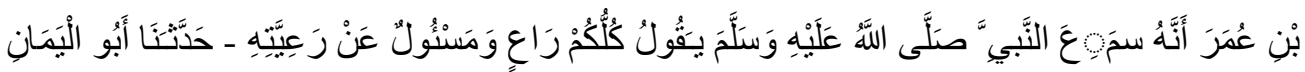

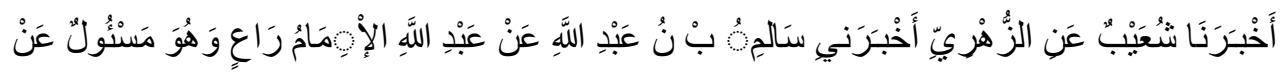

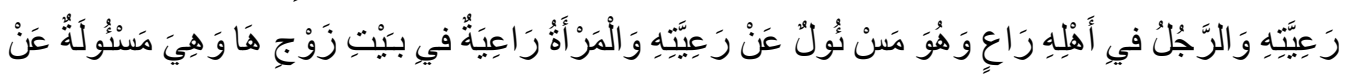

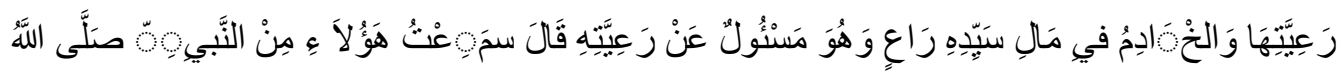

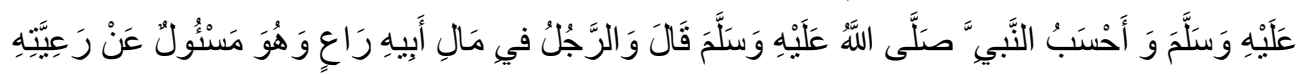

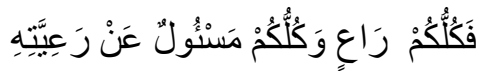




\section{PEMBAHASAN}

\section{Terma-terma Kepemimpinan}

Kepemimpinan merupakan kata yang mengandung makna ganda yakni pemimpin dan yang dipimpin. Kepemimpinan dapat terlaksana bila unsur pemimpin dan yang dipimpin berkolaborasi dengan baik. Dalam literatur Arab, kepemimpinan dinyatakan dalam kata yang bervariasi, yakni juga, kepemimpinan dan dipimpin yang, pemimpin makna pada berkisar, sama umum secara makna mempunyai selain

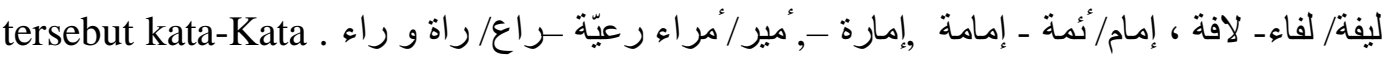
mempunyai makna khusus sesuai dengan fungsi penggunaannya dalam ayat alQur'an dan hadis. Kata-kata tersebut akan diuraikan secara terperinci berdasarkan kosa kata, frase dan kalimat, sebagai berikut:

a. Kata رعيّةــراع/ راة و راء

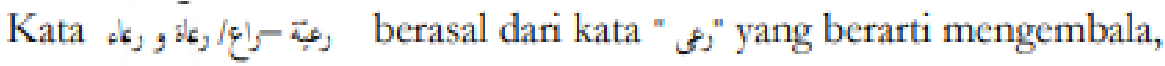
memimpin mengatur, menjaga, memelihara dan mempertimbangkan, dalam

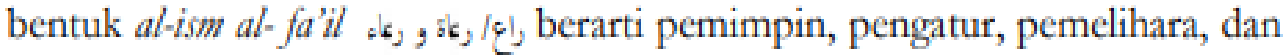
dalam bentuk ريقية mengandung makna yang dipimpin atau rakyat. Kata juga merupakan bentuk al-masdar al-sina'i yakni masdar yang dibentuk dengan menambahkan al-harf al-ya' al-nisbab dan al-ta' al-ta'nis semakna dengan al-masdar sang bermakna kepemimpinan. ${ }^{49}$

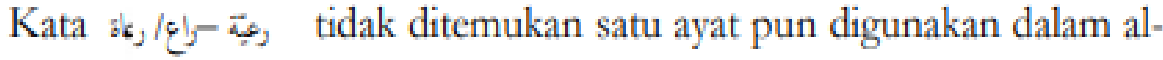
Qur'an, kecuali kata الرغ (pengembala-pengembala). Adapun kata-kata yang terdapat dalam ayat al-Qur'an yang mempunyai akar kata yang sama, adalah Kata-kata tersebut dalam al-Qur'an disebutkan sebanyak 10 kali dalam 9 surah. Dari semua kata-kata tersebut yang mempunyai pengertian yang berkaitan dengan kepemimpinan adalah kata رثوها (memeliharanya) dan (pemeliharaanya) teradapat dalam QS alHadid/57: 27, بورن (gembalakanlah) dalam QS Taha/20: 54, (memelihara) dalam QS al-Mu'minun/23: 8 dan QS al-Ma'arij/70: 32, الرغاء (pengembala-pengembala) dalam QS al-Qasas/28: $23 .{ }^{50}$

Dari berbagai ayat al-Qur'an tersebut yang sangat erat kaitannya dengan kepemimpinan adalah QS Taha/20: 54, QS al-Qasas/28: 23, QS alMu'minun/23: 8 dan al-Ma'arij/70: 32, sebagai berikut:

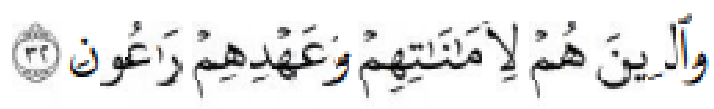


Terjemahnya : Dan orang-orang yang memelihara amanat-amanat (yang dipikulnya) dan janjinya.

Berdasarkan empat ayat al-Qur'an tersebut dapat dipahami bahwa kepemimpinan dengan akar kata " رعى "yang digunakan dalam hadis dengan kata ثةرعى mengandung pengertian sebagai berikut:

$\checkmark$ Kepemimpinan merupakan upaya memelihara atau pemeliharaan terhadap amanah dan janji sebagai seorang pemimpin,

$\checkmark$ Kepemimpinan merupakan kegiatan pelayanan yang maksimal terhadap yang dipimpin sebagaimana layaknya seorang pengembala terhadap ternaknya.

Kepemimpinan dalam arti pemeliharaan terhadap amanah dan janji sebagai seorang pemimpin yang dinyatakan dengan kata "راعون" merupakan pengertian yang sejalan dengan makna yang dikehendaki dalam hadis tentang hakikat kepemimpinan yakni adanya tanggungjawab terhadap yang dinyatakan

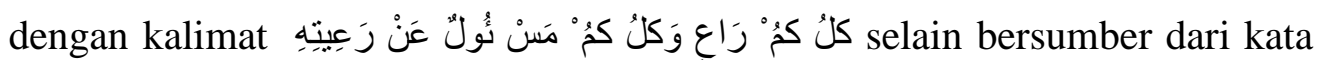
أرون bentuk jamak dari term alra'in ( الراع pada dasarnya berarti penggembala yang bertugas memelihara binatang, baik yang terkait dengan pemberian makanan maupun dengan perlindungan dari bahaya. Namun dalam perkembangan selanjutnya, kata tersebut juga dimaknai pemimpin, karena tugas pemimpin sebenarnya hampir sama dengan tugas penggembala yaitu memelihara, mengawasi dan melindungi orang-orang yang dipimpinnya.

\section{b. Kata إمارة-,مير/مراء}

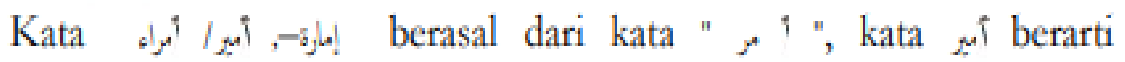
memerintahkan, menguasai dan mempengaruhi, merupakan bentuk al-ism almusyabbabab bi ism al-fa'il dari akar kata amara yang berarti pemerintah, penguasa atau amir. Kata " إبرة " merupakan bentuk al-ism al-masdar dari kata " " pang mengandung pengertian " artinya keamiran. ${ }^{53}$ " Kata keamiran mengandung pengertian kepemimpinan. Namun pada dasarnya kata amara memiliki lima makna pokok, yaitu antonim kata larangan, tumbuh atau berkembang, urusan, tanda, dan sesuatu yang menakjubkan. 
Kata مر اء/ مبر -, مُارةًا dengan segala bentuk derivasinya disebutkan dalam alQur'an sebanyak 246 kali, dan hanya satu ayat al-Qur'an yang menggunakan kata “ مارةً "yakni terdapat dalam QS Yusuf/12: 53.55 Ayat al- Qur'an tersebut tidak mengisyaratkan tentang kepemimpinan secara nyata, tetapi secara tersirat dapat dipahami bahwa kepemimpinan dalam kaitan dengan kata “ مارةً " tidak memperturutkan hawa nafsu seperti Nabi Yusuf dalam ayat al-Qur'an tersebut. Kepemimpinan dalam pengertian ini adalah upaya mengolah dan mengendalikan segala yang dipimpin termasuk hawa nafsu ke arah yang baik dan bermanfaat. Dalam al-Qur'an, kata amir tidak pernah ditemukan, yang ada hanya kalimat "مر أ ولىى"yang berarti pemimpin urusan atau pemilik urusan, yakni pemerintah, sebagaimana disebutkan dalam QS al-Nisa/4: 59, sebagai berikut :

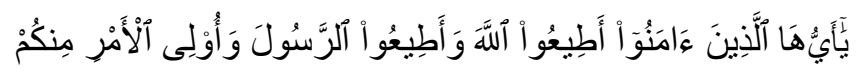

Terjemahnya : Hai, orang-orang yang beriman, taatilah Allah dan taatilah Rasul (Nya), dan ulil amri di antara kamu.

Para ulama berbeda pendapat tentang arti ulil amri tersebut. Ada yang menafsirkan dengan kepala Negara, pemerintah dan ulama. Bahkan orangorang Syi'ah mengartikan ulil amri dengan imam-imam mereka yang ma'sum. Sekalipun di dalam al-Qur'an tidak pernah ditemukan, ternyata kata amir itu sendiri sering digunakan dalam beberapa hadis. Misalnya saja, hadis riwayat al-Bukhari dari Abu Hurairah ra.

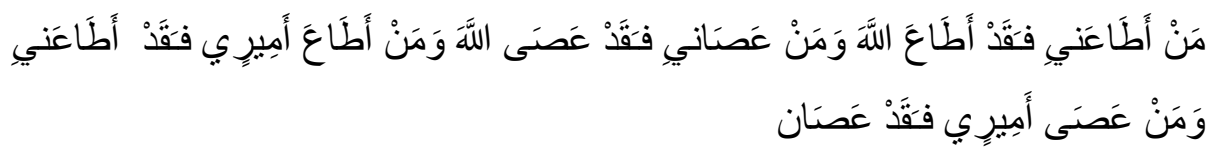

Artinya: "Barangsiapa yang mentaatiku maka sungguh ia telah taat kepada Allah, dan barangsiapa yang durhaka kepadaku maka sungguh ia telah durhaka kepada Allah. Dan barangsiapa yang taat kepada amir- ku maka sungguh ia telah taat kepadaku, barangsiapa yang durhaka kepada amir-ku maka sungguh ia telah durhaka kepadaku". 
Berdasarkan hadis tersebut, term umara atau amir dan ulil amri berkonotasi sama, yakni mereka yang mempunyai urusan dalam kepemimpinan karena memegang kendali masyarakatnya. H.A. Djazuli dalam bukunya Fiqh Siyasah menjelaskan bahwa term amir atau ulil amri dari sisi fiqh dusturi60 adalah ahl al-hal wa al-'aqd, yaitu orang yang memegang kekuasaan tertinggi dalam pemerintahan dan atau mempunyai wewenang membuat undang-undang yang mengikat kepada seluruh ummat di dalam hal-hal yang tidak diatur secara tegas oleh al-Qur'an dan hadis.61 Berkaitan dengan ayat al-Qur'an tersebut, yang bermakna pemimpin, maka kepemimpinan dalam hal ini adalah upaya atau kegiatan seorang pemilik atau penguasa segala urusan atau pemerintah, kepala negara untuk senantiasa mengarahkan yang dipimpinnya berpedoman kepada petunjuk Allah swt dan Rasul sebagai syarat untuk mendapatkan keberhasilan dalam kepemimpinan. Dalam hadis,

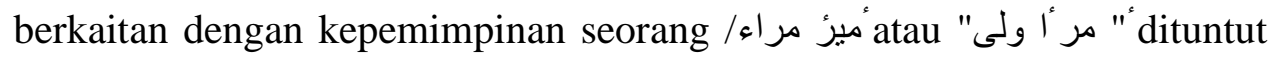
tanggung jawab penuh terhadap yang dipimpin dan mempertanggungjawabkan kepemimpinan yang dilakukan terhadap Allah

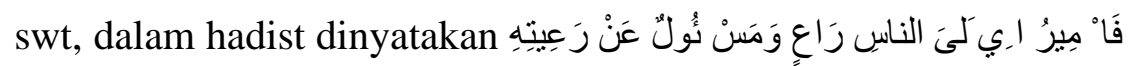

C. Kata مام/ئمة - إمامة

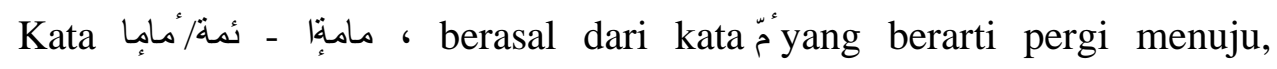
bermaksud, menyengaja, menjadi imam, dan memimpin, sementara kata مامةًا adalah bentuk al-Ism al-masdar dari kata Menurut Ibn Manzur di dalam Lisan al-'Arab, kata imam mempunyai beberapa arti, diantaranya berarti setiap orang yang diikuti oleh suatu kaum, baik untuk menuju jalan yang lurus maupun untuk menuju jalan yang sesat (QS al-Isra'/17: 71), imam juga berarti misal (contoh, teladan), Imam juga dapat berarti "benang yang dibentangkan di atas bangunan untuk dibangun dan guna menyamakan bangunan tersebut.

Ibn Faris di dalam Maqayis al-Lugah menyebutkan bahwa kata imam memiliki dua makna dasar, yaitu "setiap orang yang diikuti jejaknya dan didahulukan urusannya", karena itulah Rasulullah saw disebut sebagai imam al-aimmah dan khalifah sebagai pemimpin rakyat sering juga disebut imam al- ra'iyyah atau dalam hadis digunakan kata al-imam al-a'zam. Selain 
itu, Ibn Faris juga menyebutkan imam dalam arti "benang untuk meluruskan bangunan".64 Dalam al-Qur'an kata مامةًا- ـعمة/ُمَامِ dengan segala bentuk

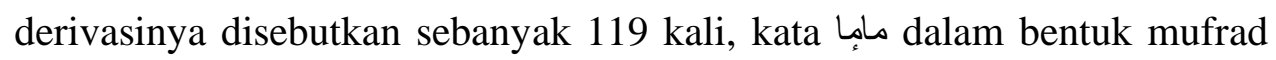
sebanyak 7 kali dan dalam bentuk jamak ( نُمة (sebanyak 5 kali.65 Bentuk kata " mengandung pengertian yang bervariasi, yakni berarti jalan (QS al-Hijr/15: 79), kitab (QS Yasin/36: 12), pedoman dan petunjuk (QS Hud/11: 17 dan QS al-Ahqaf/46: 12), pemimpin yang dimaksudkan adalah Nabi Ibrahim dan keturunannnya ( QS al-Baqarah/2: 124), serta kepemimpinan yang diserahkan kepada manusia (QS al-Furqan/25: 74 dan QS al-Isra'/17: 71), dan dalam bentuk jamak ( نُمة (memiliki pergertian yang pada hakikatnya satu makna yakni pemimpin. Akan tetapi pemimpin yang dimaksudkan adalah pemimpin dari bani Israil (QS al-Sajadah/32: 24), Fir'aun dan pengikutnya (QS al-Qasas/28: 41), Manusia (QS al-Qasas/28: 5), Nabi Ibrahim dan keturunannya (QS al-Anbiya'/21: 73), orang-orang kafir (QS al-Taubah/9: 12).

Meskipun pemimpin dan kepemimpinan dinyatakan dalam al- Qur'an dengan berbagai maksud, namun pada hakikatnya manusia adalah merupakan tokoh utama yang diserahkan tanggung jawab kepemimpinan dari Allah swt, seperti disebutkan dalam QS al-Isra'/17: 71, sebagai berikut:

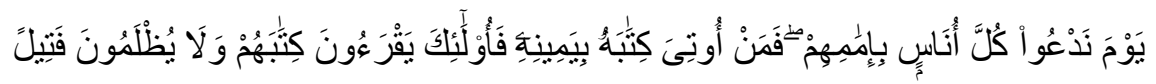

Terjemahnya : (ingatlah) suatu hari (yang di hari itu) Kami panggil tiap manusia (umat) dengan pemimpinnya; dan Barangsiapa yang diberikan kitab amalannya di tangan kanannya maka mereka ini akan membaca kitabnya itu, dan mereka tidak dianiaya sedikitpun.

Penggunaan term imam bila dikaitkan dengan ibadah shalat, dapat melahirkan beberapa makna filosofi, diantaranya imam kedudukannya selalu di depan, berarti pemimpin dalam mejalankan kepemimpinan harus senantiasa menjadi contoh teladan yang selalu diikuti oleh yang dipimpin termasuk segala gerak gerik dan tingkah laku dalam kepemiminan, baik dari 
segi ibadah dalam kedekatan dengan Tuhan maupun dalam kegiatan hidup dilingkungan, wilayah, daerah, bahkan bumi Allah swt. Sehingga term imam lebih dikonotasikan sebagai orang yang menempati kedudukan/jabatan yang diadakan untuk mengganti tugas kenabian di dalam memelihara agama dan mengendalikan dunia.

Berdasarkan penyebutan ayat al-Qur'an mengenai pemimpin dengan pengunaan kata نُمة/ مُامِام disertai makna yang bervaiasi memberikan petunjuk bahwa kepemimpinan adalah:

$\checkmark$ Jalan, pedoman dan petunjuk yang bersumber dari kitab al-Qur'an yang senantiasa diikuti dan dipedomani.

$\checkmark$ Pemberian dan anugrah dari Allah swt sebagai amanah, dengan segala kekuasaannya menjadikan segala yang dikehendaki sebagai pemimpin, yakni kitab al-Qur'an, para Nabi, manusia baik yang berada dijalan yang lurus maupun kaum kafir.

$\checkmark$ Segala sesuatu yang terlaksana berupa memberi peringatan, mempengaruhi sebagai akibat adanya pemimpin-pemimpin yang bervariasi tersebut yang diangkat oleh Allah swt, yakni al-Qur'an sebagai imama merupakan pedomam dan petunjuk, para nabi serta manusia yang beriman dan bertaqwa sebagai imama memberi peringatan dan menunjukkan jalan kebenaran, , dan kaum kafir sebagai pemimpin yang membawa jalan ke neraka.

\section{d. Kata الخليفة}

Kata خerasal dari kata " خلفية/خلناء- خلافة " yang berarti menggantikan, berbeda, berubah dan memperbaiki, dalam bentuk al-ism almasdar, yakni فلافة mengandung makna penggantian, atau kekhalifaan. ${ }^{6} 8$ Disebut khalifah juga berarti di belakang, karena yang menggantikan selalu

berada di belakang atau datang di belakang, sesudah yang digantikan. Kekhalifaan pada dasarnya merupakan kata yang memiliki makna yang sama dengan keamiran dan kepemimpinan.

Kata ليفة merupakan kata yang berbentuk al-sifah al-musyabbahab bi alism al-fa'il yang mengandung makna pelaku, sehingga kata ليفة berarti pengganti, pemimpim dan khalifah. Ungkapan khalifah lebih dapat 
diartikan makhluk yang dipercayakan dan diberi tugas oleh Allah untuk mengelola dan memanfaatkan seluruh potensi alam sesuai dengan tuntunannya, manusia ibarat wakil Allah swt

Di dalam al-Qur'an, kata khalifah dalam bentuk mufrad disebut pada dua konteks. Pertama, dalam konteks pembicaraan tentang Nabi Adam as. Konteks ayat ini menunjukkan bahwa manusia dijadikan khalifah di atas bumi ini bertugas memakmurkannya atau membangunnya sesuai dengan konsep yang ditetapkan oleh Allah. Kedua, di dalam konteks pembicaraan tentang Nabi Daud as. Konteks ayat ini menunjukkan bahwa Daud menjadi khalifah yang diberi tugas untuk mengelola wilayah yang terbatas. Dalam bentuk jamak ( لائف (disebutkan sebanyak 4 kali, (QS al-An'am/6: 165, QS Yunus/10: 14, 73 dan QS Fatir/35: 39), dalam bentuk jamak ( لفاء ) disebutkan sebanyak 3 kali (QS al-A'raf/7: 69, 74 dan QS al-Naml/27: 62), salah satu diantaranya sebagai berikut:

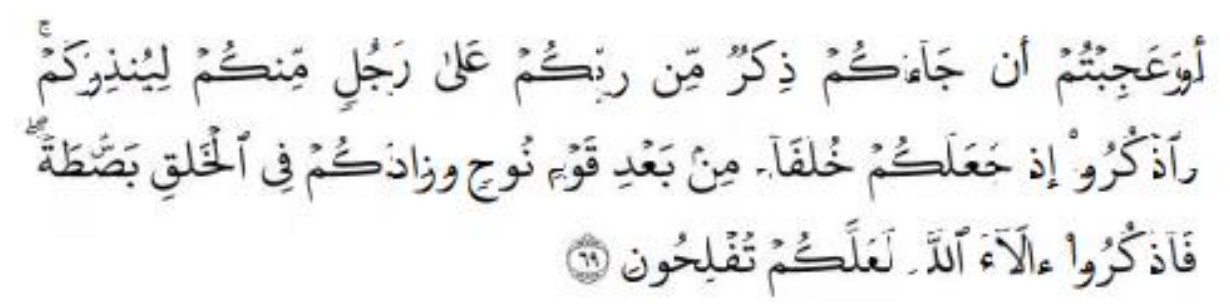

Terjemahnya: Dan ingatlah olehmu di waktu Tuhan menjadikam kamu pengganti- pengganti (yang berkuasa) sesudah kaum 'Aad dan memberikan tempat bagimu di bumi. kamu dirikan istana-istana di tanah-tanahnya yang datar dan kamu pahat gunung-gunungnya untuk dijadikan rumah; Maka ingatlah nikmat-nikmat Allah dan janganlah kamu merajalela di muka bumi membuat kerusakan

Penggunaan kata khalifah di dalam ayat-ayat al-Qur'an tersebut, baik dalam bentuk tunggal maupun plural dapat dipahami bahwa kata-kata tersebut lebih dikonotasikan pada pemimpin yang diberi kekuasaan untuk mengelola suatu wilayah di bumi. Muhammad Baqir Al-Sadr dalam buku Al- Sunan Al-Tarikhiyah fi Al-Qur'an dalam Quraish Shihab, mengemukakan bahwa kekhalifahan atau kepemimpinan yang disebutkan dalam al-Qur'an khalifah, khalaif dan khulafa' mempunyai empat unsur 
yang saling terkait, yakni manusia sebagai khalifah, khalaif dan khulafa', alam Raya dalam al- Qur'an 'al-Ard., hubungan manusia dengan alam dan manusia lainnya serta unsure ke empat adalah Allah swt pemberi penugasan dan amanah kekhalifahan atau kepemimpinan.

Makna penggantian yang disebutkan al-Qur'an adalah penggantian generasi dan penggantian kepemimpinan. Pengganti generasi, yakni suatu generasi yang taat dganti dengan genarasi pembangkang terhadap perintah Allah dan penggantian kepemimpinan, yakni penggantian kepemimpinan umat seperti presiden, raja juga dalam skala kecil, seperti organisasi sosial, kemasyarakatan dan politik.

Berdasarkan uraian tersebut dapat disimpulkan bahwa kepemimpinan atau kekhalifahan mengandung pengertian:

$\checkmark$ Kata khalifah, khalaif dan khulafa' menunjukkan manusia yang diberi kekuasaan oleh Allah swt mengelola wilayah (bumi), luas maupun tebatas.

$\checkmark$ Khalifah merupakan makhluk berpotensi, secara aktual dapat melakukan kekeliruan dan kesalahan akibat mengikuti hawa nafsu, baik Nabi Adam maupun Nabi Daud diberi peringatan agar tidak mengikuti hawa nafsu (QS Sad/38: 26, dan QS Taha/20: 16).

$\checkmark$ Pengelolaan manusia terhadap alam atau bumi merupakan kegiatan manusia yang berkolaborasi dengan alam yang didalamnya tersirat makna kegiatan kepemimpinan atau khalifahan, dalam al-Qur'an dimaksudkan untuk menguji kemampuan manusia, dalam hadis dimaksudkan untuk diminta pertanggungan jawaban terhadap pengelolaan kepemimpinan dan kekhalifaan yang dilakukan.

$\checkmark$ Khalifah lebih kepada makna wakil Allah swt di bumi melakukan kepemimpinan dan pemakmuran, pengelolaan bukan kerusakan lingkungan alam raya. 


\section{Kepemimpinan menurut Para Ahli}

Kepemimpinan dalam bahasa Inggris disebut dengan leadership, secara etimologi berarti daya memimpin atau kualitas seorang pemimpin atau tindakan dalam memimpin, atau kemampuan seseorang untuk meyakinkan orang lain agar dengan suka rela mau diajak untuk melaksanakan kehendak atau gagasan sang pemimpin. Kepemimpinan didefinisikan oleh beberapa tokoh sebagai berikut :

$\checkmark$ Menurut James M. Black dalam bukunya Management, A Guide to Exectutive Command mengatakan bahwa kepemimpinan adalah kemampuan meyakinkan orang lain supaya bekerjasama di bawah pimpinannya sebagai suatu tim untuk mencapai atau melakukan suatu tujuan tertentu.

$\checkmark$ Menurut Kreiner bahwa kepemimpinan adalah proses mempengaruhi orang lain yang mana seorang pemimpin mengajak anak buahnya secara sukarela berpartisi-pasi guna mencapai tujuan organisasi.

$\checkmark$ Hersey menambahkan bahwa kepemimpinan adalah usaha untuk mempengaruhi individual lain atau kelompok. Seorang pemimpin harus memadukan unsur kekuatan diri, wewenang yang dimiliki, ciri kepribadian, dan kemampuan sosial untuk bisa mempengaruhi perilaku orang lain.

$\checkmark$ Ordway Tead memberi arti kepemimpinan sebagai kemampuan untuk mempengaruhi orang-orang untuk bekerjasama ke arah berbagai tujuan yang sama-sama mereka inginkan.

$\checkmark$ Sedangkan Tannenbaum dan Fred Massarik mengatakan bahwa kepemimpinan selalu bersangkutan dengan usaha-usaha pada pihak seorang pemimpin (yang mempengaruhi “influencer") untuk mempengaruhi seorang pengikut (yang dipe-ngaruhi “influencee”) atau pengikut-pengikut dalam suatu situasi.

Dari beberapa pengertian kepemimpinan di atas, dapat disimpulkan bahwa hakekat kepemimpinan adalah kemampuan untuk mempengaruhi pihak lain. Keberhasilan seorang pemimpin tergantung kepada kemampuannya untuk mempengaruhi. Kepemimpinan dapat diartikan sebagai kemampuan seseorang untuk 
mempengaruhi orang atau orang- orang lain melalui komunikasi, baik langsung maupun tidak langsung, dengan maksud untuk menggerakkan orang-orang tersebut agar dengan penuh pengertian, kesadaran, dan senang hati bersedia mengikuti kehendak- kehendak pemimpin tersebut. Seorang pemimpin yang efektif adalah seorang yang memiliki kemampuan tersebut. Dengan kolaborasi makna kepemimpinan dengan yang dikehendaki ayat al-Qur'an dan hadis, maka kepemimpinan hak yang melekat pada setiap manusia dan dipertanggungjawabkan.

\section{a) Kandungan Hadis}

Kandungan atau isi pesan yang disampaikan hadis hendaknya merupakan pesan yang dapat dipedomani dan tidak bertentangan dengan misi kerasulan Nabi Muhammad saw dan tidak bertentangan dengan perkembangan kehidupan umuat. Dalam mengamalkan hadis Nabi saw dibutuhkan pengetahuan akan makna subtantif dan formil dari suatu hadis. Secara tekstual, kandungan hadis Nabi menunjukkan makna formil, tetapi dalam pengamalannya membutuhkan pemahaman makna secara subtantif. Berdasarkan makna kandungan hadis Nabi saw tersebut, maka hadis yang berbunyi راع كلكم secara formil menerangkan tentang hakikat kepemimpinan, yakni:

$\checkmark$ setiap muslim dalam berbagai posisi dan tingkatannya, mulai dari tingkatan pemimpin rakyat sampai pada tingkatan pengembala adalah pemimpin, termasuk pada tingkatan memimpin diri sendiri. Semua orang pasti memiliki tanggung jawab dan akan dimintai pertanggungjawabannya oleh Allah swt. atas kepemimpinannya kelak di akhirat.

$\checkmark$ Frasa menyirapkan makna bahwa setiap orang memiliki beban tanggung jawab kepemimpinan, apapun posisi dan status orang tersebut, apapun jenis kelamin orang tersebut. Semua memiliki tanggung jawab kepemimpinan dan kelak akan dimintai pertanggungjawaban atas kepemimpinan yang diperankannya.

$\checkmark$ Adanya klasifikasi pemimpin, yakni Pemimpin masyarakat ( مير ا I imam (al imam) Laki-laki pemimpin dalam keluarganya. Perempuan pemimpin dalam rumah suaminya. Pembantu pemimpin atas harta majikannya. Bahkan anak pun menjadi pemimpin terhadap harta orang tuanya, merupakan wujud taggung jawab terhadap masing-masing tugasnya. 
Secara subtantif hadis tentang hakikat kepemimpinan tersebut mengandung makna sebagai berikut:

$\checkmark$ Setiap orang berhak menjadi pemimpin dalam kelompoknya tanpa harus melihat faktor keturunan, harta dan ketenaran dll, melainkan berdasarkan fitrahnya sebagai pemimpin atau berdasarkan kemampuan yang dimiliki.

$\checkmark$ Adanya fungsi-fungsi kepemimpinan yang disebutkan dalam hadis tersebut, seperti amir, Imam, rajul, mar'ah, 'abd atau khadim mengandung makna pembangian job description atau lebih mengarah pada manajemen kepemimpinan.

$\checkmark$ Wujud tanggung jawab yang sesungguhnya adalah kelak dihadapan Allah swt, namun dalam kepemimpinan tanggung jawab harus selalu ada dihadapan manusia lainnya yang dipimpin dalam bentuk laporan kegiatan.

$\checkmark$ Secara subtantif, hadis tersebut mengandung makna kepemimpinan yang demokratis. Kepemimpinan demokratis pemimpin memperhitungkan aspirasi yang dipimpinnya, bawahan ikut bertanggungjawab dalam pengambilan keputusan, artinya selain pemimpin tertinggi, bawahan juga menjadi pemimpin dalam tugasnya. Hal ini didukung oleh status manusia sebagai khalifah di bumi (QS al-Baqarah/2: 30).

Makna subtantif hadis tersebut, dilandasi oleh QS Yunus/10: 14, sebagai berikut:

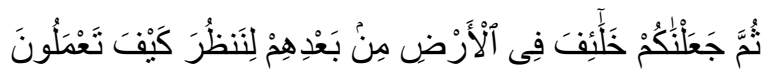

Terjemahnya: Kemudian Kami jadikan kamu pengganti-pengganti (mereka) di muka bumi sesudah mereka, supaya Kami memperhatikan bagaimana kamu berbuat.

Ayat al-Qur'an tersebut, menantang manusia sebagai pemimpin, sebagai khalifah yang dituntut melakukan kepemimpinan sesuai kondisi yang dipimpin, selanjutnya Allah swt yang akan menilai hasil kepemimpinan manusia sebagai pemimpin atau khalifah. Oleh sebab itu, setiap muslim harus berusaha untuk menjadi pemimpin yang paling baik dan segala tindakannya hendaknya tanpa didasari kepentingan pribadi atau kepentingan golongan tertentu. Akan tetapi, 
menjadi pemimpin yang adil dan betul-betul memperhatikan dan berbuat sesuai dengan aspirasi yang dipimpinnya.

\section{b) Analisis Pengembangan}

Menurut M. Quraish Shihab, terdapat beberapa ayat Al-Qur'an yang menerangkan bahwa setidaknya ada dua pokok sifat yang harus disandang oleh seseorang yang memikul suatu jabatan yang berkaitan dengan hak-hak masyarakat. Kedua hal tersebut harus diperhatikan dalam menentukan seorang pemimpin dalam tingkatan dan posisi apapun. Di antara ayat tersebut yang menerangkan tentang hal tersebut adalah ungkapan puteri Nabi Syuaib yang dibenarkan dan diabadikan dalam Q.S. Al-Qașaș 28: 26

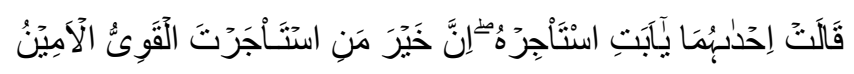

Terjemahnya: Salah seorang dari kedua wanita itu berkata: "Ya bapakku, ambillah dia sebagai orang yang bekerja (pada kita), karena sesungguhnya orang yang paling baik yang kamu ambil untuk be- kerja (pada kita) ialah orang yang kuat lagi dapat dipercaya".

Begitu pula Al-Qur'an mengabadikan alasan pengangkatan Yusuf sebagai kepala badan logistik, sebagaimana dinyatakan dalam QS Yusuf 12:54

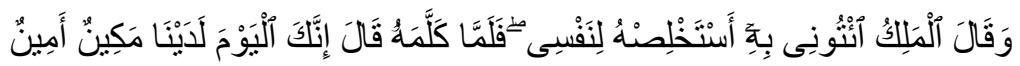

Terjemahnya : Dan raja berkata: "Bawalah Yusuf kepadaku, agar aku memilih dia sebagai orang yang rapat kepadaku". Maka tatkala raja telah bercakap-cakap dengan dia, dia berkata: "Sesungguhnya kamu (mulai) hari ini menjadi seorang yang berkedudukan tinggi lagi dipercayai pada sisi kami". 
Kedua kriteria tersebut yang menjadi landasan utama ketika Abu Bakar r.a. menunjuk Zayd bin Sābit sebagai ketua panitia pengumpulan mushaf. Alasannya antara lain tersirat dalam ungkapannya, "Engkau seorang pemuda (kuat lagi bersemangat) dan telah dipercaya oleh Rasulullah saw. untuk menulis wahyu" Bahkan Allah swt. pun memilih Jibril sebagai pembawa wahyuNya, antara lain, karena malaikat Jibril memiliki sifat kuat dan terpercaya.

Dalam Islam, ada beberapa ajaran yang dapat diramu menjadi karakteristik pemimpin Islam, yaitu :

1. Beriman dan bertakwa kepada Allah. Kepemimpinan itu terkait erat dengan pencapaian suatu cita-cita. Olehnya itu, kepemimpinan harus berada dalam genggaman tangan seorang pemimpin beriman. Allah sendiri dengan tegas me-larang kita mengangkat dan menjadikan orang-orang kafir sebagai pemimpin sesuai dalam Q.S. Ali Imran 3: 28 dan Q.S. al- Maidah 5:51.

2. Jujur dan bermoral. Pemimpin islami haruslah jujur, baik kepada dirinya sen-diri maupun kepada pengikutnya sehingga akan menjadi contoh terbaik yang sejalan antara perkataan dengan perbuatannya. Selain itu, perlu memiliki mora-litas yang baik, berakhlak terpuji, teguh memegang amah, dan tidak suka ber-maksiat kepada Allah swt. seperti korupsi, manipulasi, dusta, dan khianat.

3. Kompeten dan berilmu pengetahuan. Seorang pemimpin yang islami haruslah orang yang memiliki kompetensi dalam bidangnya, sehingga orang akan meng-ikutinya karena yakin dengan kemampuannya.

4. Peduli terhadap yang dipimpinnya. Contoh yang ditunjukkan oleh Nabi Mu- hammad saw. dalam memimpin, beliau memiliki sifat-sifat yang tinggi dan agung, seperti merasa tidak senang jika umatnya ditimpa sesuatu yang tidak di-inginkan, sangat menginginkan agar mendapat taufik dari Allah swt., serta sa-ngat belas kasihan dan penyayang kepada kaum muslimin.

5. Inspiratif. Pemimpin islami harus mampu menciptakan rasa aman dan nyaman serta dapat menimbulkan rasa optimis terhadap pengikutnya. 
6. Sabar. Seorang pemimpin islami haruslah mampu bersikap sabar dalam meng-hadapi segala macam persoalan dan keterbatasan serta tidak bertindak tergesa-gesa dalam pengambilan keputusan.

7. Rendah hati. Seorang pemimpin islami perlu memiliki sikap rendah hati de-ngan tidak suka menampakkan kelebihannya dalam bentuk riya' dan menjaga agar tidak merendahkan orang lain.

8. Musyawarah. Pemimpin islami haruslah mencari dan mengutamakan cara- cara dan jalan musyawarah untuk memecahkan setiap persoalan. 


\section{Kesimpulan}

Dari uraian-uraian dalam pembahasan makalah ini, dapatlah disimpulkan sebagai berikut :

1) Dari segi kualitas hadis-hadis tentang kepemimpinan adalah șaḥị̣ dan dapat dijadikan hujjah. Hadis-hadis tersebut merupakan hadis yang diriwayatkan secara lafal, menjelaskan tentang hakikat kepemimpinan.

2) Sikap seorang pemimpin seharusnya tidak mengkhianati yang dipimpinnya dengan cara tidak menipu dan membohonginya. Orang yang melakukan hal tersebut tidak akan mencium aroma surga apalagi masuk surga di akhirat kelak.

3) Setiap orang yang hidup di atas dunia ini, memiliki tanggung jawab pemimpin dalam dirinya masing-masing sesuai lingkup kekuasaannya, apapun posisi dan perannya.

4) Untuk itu, setiap pemimpin haruslah menegakkan keadilan karena keadilan adalah nilai universal dalam kehidupan manusia. Adil berarti tidak membeda-bedakan apa yang dipimpinnya dan tidak diskriminatif. 


\section{DAFTAR PUSTAKA}

Ahmad, Arifuddin Metode Tematik dalam Pengkajian Hadis, (Pidato Pengukuhan Guru Besar, Makassar: UIN Alauddin, 31 Mei 2007).

Arifuddin Metodologi Pemahaman Hadis, Kajian Ilmu Ma'ani al-hadis, (Cet. II; Makassar: Alauddin University Press, 2013).

Arifuddin Paradigma Baru Memahami Hadis Nabi; Refleksi Pemikiran Prof. Dr. Muhammad Syuhudi Ismail (Cet. I; Jakarta; Renaisan' 2005). Aḥmad.

Al Barry, Pius A Partanto dan M. Dahlan Kamus Ilmiah Populer (Surabaya: Arkola, t.th.).

al-Adlabi, Salah al-Din ibn Ahmad Manhaj Naqd al-Matn 'Inda Ulama' al- Hadis alNabawi, terj. Qodirun Nur dan Ahmad Musyafiq, Metodologi Kritik Matan Hadis (Ciputat; Gaya Media Pratama, 2004).

al-Baqi, Muhammad Fuad 'Abd. al-Mu'jam al-Mufahras li al-Faz al-Qur'an alKarim, (Beirut: Dar al-Fikr, 1407 H/1987 M).

al-Banjari, Rachmat Ramadhana Prophetic Leadership (Yogyakarta: DIVA Press, 2008).

al-Bukhārī, Al-Imām Abū 'Abdillah Muḥammad bin Isma'îl bin al-Mugīrah Bardizbah Șahị̣̄ al-Bukhārī,

al-Dahlawi, 'Abd al-Haq ibn Saif al-Din ibn Sa'dullah Muqaddimah fi Usul alHadis $\backslash$ (Cet. II; Beirut: Dar al-Basyair al-Islamiyah, 1406 H./1986 M.).

Ensiklopedi Hadits Kitab 9 Imam [CD ROM], www.lidwapustaka. com, 2010.

Ismail, M. Syuhudi Kaedah Kesahihan Sanad Hadis: Telaah Kritis dan Tinjauan dengan Pendekatan Ilmu Sejarah (Jakarta: Bulan Bintang, 1988).

al-Sijistānī, Al-Imām Abū Daūd Sulaymān bin al-Asy'as al-Azdī Sunan Abī Daūd, al-Syaybān̄̄, Al-Imām Abū 'Abdillah Aḥmad bin Muḥammad bin Ḥanbal Musnad al-Tahhan, Mahmud Usul al-Takhrij wa Dirasah al-Asanid (Cet. II; Riyad\{: Matba'ah al-Ma'arif, 1991). 